Journal of Humanities, Social and Management Sciences (JHSMS)

eISSN: 2788-4791 (online)

https:// doi.org/10.47264/idea.jhsms/2.2.24

Vol. 2, No. 2 (July-December 2021), 335-347

https://www.ideapublishers.org/index.php/jhsms

Research Article

\title{
The Colonial Archaeology of Taxila: A historiographical analysis
}

\author{
Ifqut Shaheen* \\ Department of History, Shaheed Benazir Bhutto Women University, Peshawar, Pakistan. \\ *Corresponding Author Emails: ifqatmahr@gmail.com | ifqutshaheen@sbbwu.edu.pk \\ Received: October 1, 2021 \\ Published: December 31, 2021
}

\begin{abstract}
Like other major archaeological sites of South Asia, the history of archaeological research at Taxila has now been one and a half century old. Taxila is situated in the Rawalpindi district of the Punjab, Pakistan. Various scholars since the mid-nineteenth century have worked in the area in order to explore and investigate its ancient history and society. Amongst them, Sir Alexander Cunningham and Sir John Marshall, both of whom served as Director Generals of the Archaeological Survey of India, stand conspicuous. This paper deals with their work and ideas, with a focus on Taxila, about the history and archaeology in the South Asian context along with assessing the colonial thought in their research works. The approach here is historiographical with a focus on socio-cultural and ethnic re/constructions by both these pioneering archaeologists. As we know that writers and researchers cannot be separated from the thought of the age they are living in, the intellectual contexts of the work of Cunningham and Marshall has also been elaborated.
\end{abstract}

Keywords: Cunningham, Marshall, South Asia, Sirkap, archaeology, survey, diffusionism.

\section{How to Cite:}

Shaheen, I. (2021). The Colonial Archaeology of Taxila: A historiographical analysis. Journal of Humanities, Social and Management Sciences (JHSMS), 2(2), 335-347. https://doi.org/10.47264/idea.jhsms/2.2.24

\section{Publisher's Note:}

IDEA PUBLISHERS (IDEA Publications Group) stands neutral regarding jurisdictional claims in the published maps and institutional affiliations.

\section{Copyright:}

(C) 2021 The Author(s), published by IDEA PUBLISHERS (IDEA Publications Group).

\section{Licensing:}

This is an Open Access article published under the Creative Commons Attribution-NonCommercial 4.0 International License (http://creativecommons.org/licenses/by-nc/4.0/) 


\section{Introduction}

In this list of the early archaeologists of Taxila, colonial workers get prominence due to their pioneering contributions. Their scholarly programmes obviously determined the course of their research and fieldworks and, no doubt, guided what may be termed as their historical and societal reconstructions. Such an approach to the colonial historiography of Taxila individuates two areas of potential investigations, namely historical and societal reconstructions of early archaeologists and scholars in relation to the archaeology of Taxila and their colonial interests and mentality.

This paper ${ }^{1}$ aims to explore and analyse these two trends and features in the works of the prominent colonial archaeologists of Taxila: Sir Alexander Cunningham and Sir John Marshall. The former worked in India during most of the nineteenth century, from 1830s to 1880s, as in military service and then as Director General of the Archaeological Survey of India. The Survey was founded as an institution in 1861 with Cunningham's efforts and vision. It was to explore and document monuments and structures of archaeological and historical interests. Cunningham carried out a great number of archaeological surveys over the decades and documented and dug hundreds of sites. In the later years of the nineteenth century, the Survey somehow suffered from inactivity due to some reasons, but the arrival of Lord Curzon as Viceroy of India ushered in a new era. He was having an astonishing interest in the built historical heritage of South Asia. He reconstituted the Survey and brought Sir John Marshall as its new Director General in 1902. He was fortunate to serve in this capacity till 1928 and finally left India in 1934. Amongst the many achievements of Marshall, he may be forever remembered for his role in the discovery of the Indus valley civilization in the late 1920s and early 1930s. Similarly, he worked for more than two decades at Taxila.

This paper, first, sets a conceptual framework followed by an overview of the historical scholarship produced by these two archaeologists and colonial thought and mentality which either shaped or inspired these historical and archaeological research.

\section{Conceptual framework}

Historiographical study indicates the state of maturity of a discipline. It critically analyses the past achievements and failures in a particular filed of research, investigates current problems and ponders upon the future prospects of finding solutions. This way, such studies help an academic discipline to grow in a consistent manner. Furthermore, 'the basic rules of historiography [...]' observes Bruce Trigger, 'require that, when different interpretations can be derived from the same body of data, historians should seek to determine whether these versions are complementary and can be synthesized into a more comprehensive, persuasive, and theoretically interesting whole, or they are contradictory, in which case new data should be sought and further analyses carried out to discover whether and to what extent each interpretation is correct' (Trigger, 1989, pp. 471-472).

History of archaeology of various areas and regions shows that such kind of historiographical considerations have played important role in the development of the discipline. It has undergone great technical and methodical and philosophical and theoretical orientations in circular manner. In this whole process archaeology has greatly been influenced by sociopolitical situation throughout its history. The first philosophical and theoretical tenor is that 
of evolutionism which obviously determined the course of archaeological activity during the nineteenth century. Racism, diffusionism and the idea of unilinear concept of development characterized evolutionary archaeology. Some societies - and obviously they were the colonized ones - were seen as static while European cultures were viewed as dynamic, resilient and capable of change and growth. Great inherent shortcomings in evolutionary archaeology such as failure to present logical explanation for societal growth and stasis, to appreciate variation in environment in terms of archaeological cultures, etc. led some archaeologists to seek for new theoretical frameworks (Trigger, 1989, pp. 166-210). Culturehistorical archaeology did emerge in the wake of such a realization.

Culture-historical archaeology dominated the scene till mid-twentieth century. Chronology, diffusionism, description, analogy and, most importantly, progress may be termed as significant features of Culture-historical archaeology. To this, as this researcher has generally observed, may be added attraction of and focus on high culture with negligible attention to the study of ways of life and other minor things in the field of historical archaeology. Two types of questions preoccupied archaeologists almost all the time viz. 'where' and 'when'. Both intended to seek for the phenomenon of cultural change a framework of explanation which was extrinsic and the idea of intrinsic factors of cultural change, or even the interplay of extrinsic and intrinsic factors, did not occur to them. This sterile situation led to disappointment of some scholars and another movement in theoretical archaeology, which nearly remained polemic in tone throughout, emerged. This came to be known as processual or New Archaeology.

\section{Historical and societal reconstructions of early archaeologists and scholars}

Colonial archaeology of Taxila exhibits philosophical concepts of both evolutionism and culture-historical archaeology. All the reports, descriptive documentations, and analytical works are freight with what may be termed as colonial thought. Ideas of biological and cultural evolution intertwined which led to division of societies into superior and inferior, dynamic, and static and progressive and vanishing. These binary oppositions sought justification for European colonialism. Division and understanding of societies in racial terms necessitated some sorts of studies and research about the subjugated peoples. This extreme racism was camouflaged in ethnographic studies and generalizations, historical reconstructions, and archaeological explanations. All this is found in works of Alexander Cunningham, John Marshall etc. about Taxila.

Cunningham's archaeological explorations at Taxila were guided by two types of historical sources namely, the classical works and Chinese pilgrims' accounts. He observes:

In comparing the existing ruins of ancient Punjâb cities with different accounts that we possess in the Chinese and classical authors, I propose to follow the footsteps of Alexander himself. I have already noticed the fact that, as the Chinese pilgrims as well as the Macedonian conquerors entered the Punjâb from the west, their routes will mutually illustrate each other. For this reason, I prefer to begin my description of the antiquities of the Punjâb near the banks of the Indus, and gradually to work my way to the eastward, in company with Macedonian soldiers of Alexander, and Buddhist pilgrims of China. With their journals in our hands, we may venture to visit the ruined cities of the Punjâb with 
the certainty that our time will not be wasted in fruitless research (Cunningham, 1871, p. 82).

Alexander Cunningham set his survey programme of the Punjab in the way which made two clearer categories of his research. These were ethnology and antiquities. This is clearly what is found in his comprehensive Memorandum to the Viceroy in 1861. 'In describing the ancient state of the Punjâb', writes Cunningham, 'the most interesting subject of enquiry is the identification of those famous peoples and cities, whose names have become familiar to the whole world through the expedition of Alexander the Great' (Cunningham, 1871, p. 01).

In studying descent of modern inhabitants of the Punjab, Cunningham takes Greek and Chinese sources along with some Indian sources as a sort of guide. He believes that peoples of those olden times made ancestry of the current inhabitants of the area. And the ruins found as scattered all through the Punjab obviously belonged to the ancestors of the present people. It is in this conceptual framework that Cunningham's studies both the people and archaeological heritage of the Punjab. He divides his report of the 1864-1865 survey into two headings of ethnology and antiquities (Cunningham, 1871). Cunningham elaborates his methodical and conceptual programme in an interesting way. 'Under the first head', he says, 'will be described the various races which have settled in the Punjâb from the earliest times down to the Muhammadan conquest, and an attempt will be made to trace the downward course of each separate tribe, until it joins the great stream of modern history' (Cunningham, 1871, p. 01). In line of this programme three main classes of peoples of the Punjab have been specified, namely 'Early Turanians, or aborigins', 'Aryas, or Brahmanical Hindus' and 'Later Turanians, or Indo-Scythians'. The first class, Cunningham states, makes non-Aryans and its sub-groups are Takkas, Megs, Dunds, Satis, Sadan and Damaras. The second category - as the name shows belongs to the so-called Aryans - is described as 'tribes of Kshatriya descent' and consists of tribes such as Suraj-Vansis, Som-Vansis, Janjuhas, Bhatis, Katris, Dogras and, probably, Awan. The last group comprises Gakkars, Kathis, Balas, Jats and Meds and Gujars (Cunningham, 1871).

As Cunningham makes his historical reconstruction in the light of literary tradition, he gives little value to other traditions - such as oral and archaeological - if they come into contradiction with written words. In contrast to popular local tradition which calls Jats, Meds (Medhs) and Gujjars as belonging to the earliest inhabitants of the Punjab, Cunningham, simply, says that he does not find reference to them in ancient texts, considers their arrival of later date (Cunningham, 1871).

Another interesting reconstruction presented by Cunningham is the close association of the Early Turanians with the city of Taxila. According to him, the name Taxila derives from name of one of the tribes of this group i.e., Takkas who were later on expelled from the areas they had occupied. Around the turn of the Common Era, Taxila was called Amanda or Amandra. Cunningham establishes an association between Amanda/ra and the modern tribe of Awan. He opines, "As the letters $m$ and $v$ are interchangeable, the two names are so precisely the same that I feel little hesitation in proposing the identification of the Awân with the people of the ancient Amanda' (Cunningham, 1871, p. 06). At the time of Alexander's invasion, Takkas had already been expelled from Taxila, probably by the Gakkars of the Later Turanians (Cunningham, 1871, pp. 6-7). While scrutinizing and synthesizing a number of ancient textual sources, Cunningham concludes: 
From all these instances, it is clear that the Takkas or Tâk cannot possibly belong to the Aryan family, and as the name of Takksila is much older than the time Alexander, it is equally certain that they do not belong to the later Turanians or Indo-Scythian. For these reasons I have assigned them to the class of early Turaninas, who were in all probability the aborigines of the country (Cunningham, 1871, p. 11).

The second significant strand of Cunningham's archaeological activity of Taxila is exploration and description of antiquities. There is no doubt that explorations and specific identifications made by Cunningham were largely dictated by historical and literary sources of the olden days. They consist of Greek sources such as works of Curtius, Arrian, Ptolemy, Pliny, Strabo, Philostratus, etc. and Chinese travelogues ${ }^{2}$ such as accounts of Faxian, Sung Yun, Xuanzang etc. (Cunningham, 1871, p. 82).

The valuable sources for Cunningham showed him the way how to plan his survey of the then Punjab. He puts down the strategy and the logic behind his planning in clear words. One cannot resist the temptation to quote it in original. It follows as:

In describing the ruined cities and ancient monuments of the Punjâb, I propose to begin on the west bank of the Indus and to work towards the east, keeping closely to the general track that was followed both by the Macedonian king and by the Chinese pilgrims. In carrying out this scheme, I will begin at Peshâwar as a well-known starting point, from which Hwen Thsang's [Xuanzang] bearings and measurements will be a guide to the identification of other places to the west of the Indus (Cunningham, 1871, p. 86). ${ }^{3}$

Taxila's identification, which is seminal study of one of the most important urban sites of South Asia, was made possible by such an approach adopted by Cunningham. In this painstaking identification of the much-forgotten city, he took great help, alongside of the extensive ruins, of the classical and Chinese sources.

Another important feature of Cunningham's survey at Taxila is collection of local traditions about the archaeological landscape of the valley. It may not be taken and dubbed as something of trivial importance or the result of dilettante attitude. Rather, getting information from local informants was a well-thought-out concept and, thus, an integral part of Cunningham's archaeological strategy (Shaheen \& Khan, 2020). It was intrinsic to orientalism especially of the nineteenth century, nay, it provided one of the bases to understanding colonized societies in an evolutionary perspective (Trigger, 1989, p. 166). ${ }^{4}$ In the report of his Taxila reconnaissance a native of the valley, Nur, dominantly sounds, though other people are also mentioned with regard to some archaeological sites and antiquities but under the general rubric of 'locals' and 'people' and not individuals by name.

Similarly, Sir John Marshall also fits in the framework of colonialist archaeology. Two main areas where he could be seen as a colonial orientalist are diffusionism and dynastic history. This is well reflected in his works on Taxila. To this may be added the fact that Marshall was a classical archaeologist and emerged on the Indian scene immediately after getting training in Greece. In other words, he was a historical archaeologist having little, or no, interest in prehistoric archaeology. 'Classical archaeologists', writes Bruce Trigger, 'remained deeply 
interested in texts and elite culture, whereas by the 1960s prehistoric archaeologists had become increasingly committed to an ecological approach' (Trigger 1989, p. 498). Obsession with Eurocentrism and elite culture could not be maintained for long. That is why Trigger remarks that 'Although some classical archaeologists attempted to break out of their traditional mode of doing archaeology in the late nineteenth and early twentieth centuries, these efforts had little impact' (Trigger, 1989, p. 500).

Against this backdrop, Marshall's work lies in the theoretical framework of culture-historical archaeology. And it is contextualization of his work at Taxila against this theoretical background that a meaning can be assigned to his historical reconstructions and archaeological explanations about the valley. He re/constructs political history of Taxila right from the period of Achaeminid Persians upto the period of White Huns. And all cultural developments and achievements are analyzed in dynastic terms. Such an approach relates to the concept and approach of diffusionism. Greeks bulk large in the whole story as cultural developments in the post-Greek periods especially of Sakas and Parthians are said to have occurred as a legacy of the Greeks. Similarly, his indifference to the prehistory of the area is also steeped in his classical background. He writes in this regard:

The truth disclosed by the hard facts of excavation is much more sober. The earliest of the remains uncovered on the site go back no further than the sixth century B.C. or thereabouts. If any settlement of the Stone, Copper or Bronze Age ever existed at this spot, it has yet to be unearthed. The only objects of a definitely prehistoric character hitherto brought to light are a few polished celts and a mace head; and these were found in strata which cannot be referred to an earlier period than the second or first century B.C. How these primitive artefacts found their way into such late strata is a matter of conjecture; it is significant, however, that four out of five of them are made of rare and particularly fine varieties of stone, viz. green epidiorite, epidote quartz, nephritic jade and blue serpentine ... and it seems more than likely, therefore, that they were preserved simply as curiosities or talismans, though another possible explanation is that stone celts such as these continued to be used for sacrificial or other ceremonial purposes long after the Stone Age had passed away (Marshall, 1951, pp. 11-12).

After this brief reference to some prehistoric finds, Marshall details upon the political and dynastic history of Taxila. What a picture emerges from Marshall's research is hardly different from the one which sees cultural patterns of the valley as being evolved along political developments and dynastic shifts. Even spread of Buddhism has been viewed dominantly, if not solely, in terms of state patronage (Marshall, 1951, p. 11). He writes, "the great majority of these monuments date from the first five centuries of the Christian era, and none of those now visible are as early as the Mauryan kings; but if the strength and vitality of a religion can be gauged from its monumental remains, no one seeing this vast galaxy of ruins can doubt the overwhelming success which ultimately rewarded Aśoka's efforts in this part of India" (Marshall, 1951, p. 25). Another intriguing point from the point of view of political expediency and presentism in history is that Marshall, on the authority of Tarn, observes that Greek rule in India, and hence at Taxila, was based on the goodwill of the subject people. Such a concept of government and administration had fascinated some Britishers in the context of British India and applying this on Greek rule might not be seen save interpreting/constructing history in modern terms and let it be said under political expediency. 


\section{Colonial tinge in the archaeology of Taxila till 1947}

Since South Asian archaeology as a whole remained till 1947 colonial in nature, the archaeology of Taxila was not an exception. This is briefly, but handsomely, summarized by Bruce Trigger as it follows:

Archaeological research in India began in a colonial setting and for a long time remained remote from traditional Indian scholarship... In the nineteenth century, amateur British archaeologists began to examine and report on megaliths, Buddhist stupas, and other monumental sites with some regularity. Often, they treated these monuments as evidence of a Golden Age in India's remote past and implied that these finds indicated that the duty of British colonial rulers was to rescue India from the decline that had followed' (Trigger, 1989, pp. 268-269).

He further writes:

In general, the British justification of colonialism was based on historical and linguistic data rather than archaeology. Colonial historians argued that cultural progress had been brought about by the migration into India of successive waves of racially superior northern peoples who introduced important innovations but then interbred with the general population. The primary message was that India was unable to change without external influences. In this scheme, the British presented themselves as the latest and more advanced standard bearers of progress in India, while acknowledging a distant ethnic affinity to the allegedly racially purer Indo-European elements in the population of northern India. In this way, the Indian caste system was racialized, and the higher castes portrayed as a separate ethnic group (Trigger 1989, p. 269).

From Trigger's analysis it becomes clear that it was colonial thought which greatly contributed to development of archaeology in Indo-Pakistan. It manifested itself in Britishers' presentation of themselves as 'benevolent' and 'enlightened' rulers and the construction of racial superiority of the so-called Aryans. They claimed it as 'Imperial' duty to study and rescue the heritage of South Asia. It is clear from Lord Canning's minutes as regarding Cunningham's appointment as Archaeological Surveyor in 1862:

But so far as the Government is concerned, there has been neglect of a much cheaper duty, - that of investigating and placing on record, for the instruction of future generations, many particulars that might still be rescued from oblivion, and throw light upon the early history of England's great dependency; a history which, as time moves on, as the country becomes more easily accessible and traversable, and as Englishmen are led to give more thought to India than such as barely suffices to hold it and govern it, will assuredly occupy, more and more, the attention of the intelligent and enquiring classes in European countries (quoted in Cunningham, 1971).

Similarly, Curzon, who is designated by Nayanjot Lahiri 'as Marshall's guru and guide' (Lahiri, 2000, p. 89), also thought Imperial. He declared it as 'Imperial' responsibility of the British government to give attention to the archaeology of the subcontinent both in terms of 
research and conservation (Chakrabarti, 1988). Rafiullah Khan has well written in this respect, 'Curzon was fully preoccupied by the moral and political magnitude of the British Empire and this very obsession "formed the mainspring of his political and intellectual outlook" ... The speech he delivered on February $6^{\text {th }}, 1900$, before the Bengal Asiatic Society at Calcutta, better illustrates this mentality as regards the Indian archaeology' (Khan, 2014, p. 227).

There is no denying the fact that all civil servants and military officers of the Empire were indoctrinated about their superiority, and they used to think imperially. In this context, one of the important sources of making things and thinking imperial was the romance and legend of Alexander of Macedonia. It was not limited to ICS officers and military officials. Nearly all the orientalists were obsessed by the legend of Alexander. Cunningham and Marshall were no exceptions to this. Like other scholars of the age, they also see no change in socio-cultural terms in the population of Taxila from inside. This was a purposeful construction and was aimed at serving colonial interests. Classical texts associated with Alexander's episode were considered as repertoires of valuable information about Indo-Pakistan subcontinent and its present was subjected to orientalists' understanding of the classics-determined past of the country. A significant study elaborates this point:

In all these cases the contemporary value placed on the classical sources relating to Alexander is impossible to miss. Robertson, Elphinstone, MacFarlane, and Nolan clearly believed this subject of the classics provided useful commentary on India's present environment, its peoples, their practices, and institutions. This tendency may appear relatively innocuous: a legitimate attempt to understand India' present better by applying the only historical framework readily available to most British scholars, soldiers, civil servants, and statesmen. And so, it seems to have been on occasion. Yet, even in the most sympathetic and sensitive hands the conflation of past and present, the use of ancient India to understand contemporary India, had sinister consequences with respect to British attitude to India and its peoples (Hagerman, 2009, p. 358).

Such an approach is also found in Cunningham's reports about the Punjab. In the 'ethnology' section of his report of 1871, he writes about different tribes of the area and locate them in ancient history with the help of ancient historical and literary sources. His presentation gives the picture of imposing the past on the present of the people of this area. It clearly reflects in the following passage:

... the Chinese pilgrim, Hwen Thsang [Xuanzang], and twice passed through Taxila, but on both occasions he avoided the country now occupied by the Gakars. As nearly two centuries and a half earlier, or in A.D. 400, another Chinese traveler, Fa-Hian [Faxian], had also avoided their country, I conclude that the Gakars of those early days had already earned the refutation, which they have since so successfully maintained (author's italics), of being the greatest plunderers in Northern India. This character of the Gakars is perhaps alluded to by Priscian when he speaks of the "savage Gargars," ... (Cunningham, 1871, p. 25). ${ }^{5}$

All the orientalists of the colonial period made romance of the Alexander's eastern adventure. 
Different researchers, investigators and intellectuals tried to explore this phase of history in vivid terms and a number of studies in this respect appeared. Initially, literary, and historical sources were perused and scrutinized in order to construct and propagate the legend of Macedonian conqueror (for a recent study see, Hagerman 2009). Later on, topographical and material/archaeological evidence was also desperately produced to add some solid evidence to this colonial enterprise. Alexander Cunningham, John Marshall and Aurel Stein may especially be mentioned here as they dedicated much of their time and energies to exploring and unearthing Greek presence in northern Indo-Pakistan. Of these scholars/orientalists, recently Stein's romance of Alexandrian legend has been critically analysed by Rafiullah Khan in the context of Swat valley and the surrounding areas (Khan, 2014). He has also examined Stein's archaeological mission into Balochistan during 1920s and 1940s in a colonial context in an unpublished paper (Khan, 2018).

Such a colonial enterprise in relation to Alexander and Greek romance bulks large in the archaeology of Taxila. Both Cunningham and Marshall did much in this field by exploring and explaining Taxilan archaeology in Alexandrian and Hellenistic terms. It was the Mohramaliaran temple which greatly attracted Cunningham. It is a temple having Greek architectural features such as Ionic pillars. Cunningham gave more attention to the site during his second visit to Taxila. He carried out digging at the site and was pleased by finding Greek architecture. He, thus, observes, 'I therefore determined on clearing out the interior, with the view of finding the shafts and capitals of the Ionic pillars and of ascertaining the use and purpose of the building. My explorations were successful in both these points, and the discovery of several portions of Ionic capitals is of special interest and value, and this is the only instance in which any remains of the Ionic order of Greek architecture have yet been found in India' (Cunningham, 1875, pp. 68-69). Another interesting point in this connection is Cunningham's reading of a Bactro-Pali inscription from Taxila. Among other things, Cunningham read in the inscription name of Greek month Paemos which obviously does not seem as being used in the text. In the same issue of the journal in which Cunningham published his article also appeared Rajendralal Mitra's observations about the former's translation and reconstruction of the inscription. Mitra identified that very month as Panchamasa, the fifth month (see Cunningham, 1864; Mitra, 1864).

This search for and romance of things Greek was taken up by Marshall to the level of amplification and popularization in the early twentieth century. It is clear from what sort of time, resources and energies were dedicated by him to the excavation and study of Sirkap city as compared to other archaeological sites of Taxila. Moreover, he sought to declare all great works and achievements such as the concept and practice of planned city and standard art and pottery patterns found at Taxila to the Greeks (Marshall, 1951, p. 40). It is his presentation/construction of binary oppositions - what were valuable and superior Greek things and what were local inferior things-which is the embodiment of colonial mentality and imperial thought. It is clear from the very first paragraph of Marshall's magnum opus, Taxila:

It is upwards of forty years since I first visited Taxila, and I still remember the thrill I got from the sight of its buried cities. At that time, I was a young man, fresh from archaeological excavations in Greece and filled with enthusiasm for any Greek; and in that far-off corner of the Punjāb if seemed as if I had lighted of a sudden on a bit of Greece itself. Doubtless the illusion was prompted in a 
large measure by Taxila's historic associations with Greece; for it was in Taxila that Alexander the Great halted and refreshed his army before advancing to do battle with Porus; and it was here that Greek kings afterwards ruled for a hundred years and left behind them an enduring legacy of Hellenistic culture. But there was more to it than that. I felt then, as I have never ceased to feel since, that there was something appealingly Greek in the countryside itself: in the groves of wild olive on the rock slopes, in the distant pine-clad hills bellow Murree, and in the chill, invigorating air that blows from the snowfields beyond the Indus. No wonder that I was all eagerness to get to work on such an alluring site and uncover with pick and spade whatever might be left of its ancient secrets (Marshall, 1951).

Similarly, the conservation and restoration programme during John Marshall's Directorship received special attention. ${ }^{6}$ It was also imperial in terms of concept and practice. Restorations were affected and conservations done without taking indigenous religious sensitivities into account. Experts with local knowledge and skills in the field of architecture were subjected to those trained persons, such western architects, and engineers, who lamentably lacked native knowledge and religious-cultural appreciation and understanding. In this context, some monuments suffered from lack of originality even to the extent of beyond any recognition (Guha 2010). The restoration and conservation works have been analysed by scholars in their socio-political milieu. It intimately interacted with what has been termed above as Curzon's imperial thought. The very concept of conservation was embedded to the imperial thought as it is clear from Curzon's various speeches (Ronaldshay, 1928). Sudeshna Guha has presented interesting analysis in this respect. She says:

Curzon was keen to rectify his predecessors' desultory schemes of repairs and restorations, initiated mainly from the 1880s. Hence, one of the main thrusts of his archaeological policy was to see that the incumbent Director General of the Survey "secure that the ancient monuments of the country are properly cared for, that they are not utilized for purposed which are inappropriate or unseemly, that repaired are executed when required, and that any restorations which may be attempted are conducted on artistic lines." His directions for renovating the three Mughal forts at Delhi, Agra, and Lahore, and the more prominent of the 'Mohammedan' monuments outside their precincts, were by and large followed by Marshall, who completed many of his projects by the first decade of the twentieth century... These restorations, which are classic examples of Marshall's skills at literally piecing together the Mughal 'debris', resonated with the will of the British Raj to appropriate the grandeur of their illustrious predecessors for establishing within native their own royal authority (Guha, 2010, p. 41).

In the context of this conservation scheme, Marshall's preservation, and conservation at Taxila make good enough sense. Nearly all-important excavated sites were conserved and even restored if needed. Dharmarajika, Jaulian, Mohra-murado and above all the urban site of Sirkap were invested with great energies and resources in terms of time and money vis-à-vis conservation and restoration. K. N. Dikshit describes it as follows:

In Punjab, the most important monuments that have been conserved are the group in and around Taxila, brought to light in the course of Sir John Marshall's 
prolonged excavations. Here the excavated remains of the different cities that arose one after another and the religious establishments that were located in the outskirts were conserved with great care and forethought. The most striking among the Buddhist sites are the Dharmarājikā stupa, where a large complex of minor buildings was uncovered round an ancient stupa erected by Asoka himself; Jaulian, the beautiful stupas and monasteries of which, embellished by stucco figures of Buddha, have been preserved in situ; the Kunāla stupa at the southern end of the city of Sirkap; Kalawan and Mohra Moradu, where valuable monastic establishments were discovered. The extensive remains of the city of Sirkap have also been admirably preserved, care being taken to distinguish the construction of the different periods (Dikshit, 1939b, pp. 4748).

It is important to note that beside imperial considerations, Marshall's interest in conservation was also triggered by an academic concern. He wanted to preserve the monuments and especially structures of excavated areas in order that the future generations of scholars may be able to examine the sites themselves and to re-visit the explanations and interpretations of archaeological objects given by the excavators and primary scholars (Marshall, 1951). And this is where Marshall and his vision for future archaeological scholarship may be appreciated.

\section{Conclusion}

This study shows not only the interests and concerns archaeologists of British India were having but also what types of colonial thoughts and considerations motivated archaeological research. On the whole this period's archaeological activity in South Asia may be seen as characterized by racial issues, cultural change through diffusion and preservation of the heritage of the area in a way which if sometimes would have been valuable, on other occasion would have occurred to be blind to local sensitivities and sensibilities. And this necessitates having a critical, revisionist and postcolonial attitude towards studying colonial archaeological activities, policies and literature. This is particularly required in Pakistan. Unlike other South Asian countries, much work in this direction has been done in India. Archaeology in the region, as we know very well, needs to be given new impetus through critical historiographical approaches and reappraisal.

\section{References}

Chakrabarti, D. K. (1988). A history of Indian Archaeology: from the beginning to 1947. Munshiram Manoharlal Publishers.

Cunningham, A. (1864). Remarks on the Bactro-Pali inscription from Taxila. Journal of the Asiatic Society of Bengal XXXII (I-IV), 139-151.

Cunningham, A. (1871). Four reports made during the years 1862-63-64-65, archaeological survey of India II. Government Central Press.

Cunningham, A. (1875). Report for the Year 1872-73, Archaeological Survey of India. Office of the Superintendent of Government Printing, Calcutta.

Dikshit, K. N. (1939a). Conservation: (a) Conditions and methods. In J. Cumming (Ed.), Revealing India's past: A co-operative record of archeological conservation and exploration in India and beyond (pp. 33-42). The India Society. 
Dikshit, K. N. (1939b). Conservation: (b) Buddhist and Hindu Monuments. In J. Cumming (Ed), Revealing India 's past: A co-operative record of archceological conservation and exploration in India and beyond (pp.43-55). The India Society.

Gkiasta, M. (2008) The historiography of landscape research on Crete. Leiden University.

Guha, S. (2010). Archaeology, photography, histories. In S. Guha (Ed.), The Marshall Albums: Photography and Archaeology (pp. 10-67). Mapin Publishing.

Hagerman, C. A. (2009). In the footsteps of the 'Macedonian conqueror': Alexander the Great and British India. International Journal of the Classical Tradition, 16(3), 344-392. https://link.springer.com/article/10.1007/s12138-009-0130-6

Khan, R. (2014). Beginning of Archaeology in Malakand-Swat (1896-1926): Protagonists, fieldwork and the legal framework. $\mathrm{PhD}$ Dissertation, Taxila Institute of Asian Civilizations, Quaid-i-Azam University, Islamabad, Pakistan.

Khan, R. (2018). Sir Aurel Stein's archaeological expeditions into Balochistan, Pakistan: An historical analysis. Journal of the Punjab University Historical Society, 31(2).151-165. http://pu.edu.pk/images/journal/HistoryPStudies/PDF_Files/14_v31_2_july2018.pdf

Lahiri, N. (2000). Coming to Grips with India's Past and her 'Living Present': John Marshall's Early Years (1902-06)-Part II. South Asian Studies, 16(1), 89-107. https://www.tandfonline.com/doi/pdf/10.1080/02666030.2000.9628582

Marshall, J. (1951). Taxila: An illustrated account of archaeological excavations carried out at Taxila under the orders of the Government of India between the years 1913 and 1934. Vol. I, Structural remains. Royal Book Company, Karachi.

Mitra, Babu Rajendralala. (1864) Note on Major-General Cunningham's remarks on the Bactro-Pali Taxila inscription. Journal of the Asiatic Society of Bengal XXXII (I-IV), 151-161.

Oberoi, H. (n.d.). Empire, orientalism and native informants: The scholarly endeavours of Sir Attar Singh Bhadour. http://www.global.ucsb.edu/punjab/journal/v17_12/articles/JPS_17_nos_1-2_Oberoi.pdf

Ronaldshay, E. O. (1928). The life of Lord Curzon: being the authorized biography of George Nathaniel Marquess Curzon of Kedleston, Vol 3. Ernest Benn Ltd. https://ir.nbu.ac.in/bitstream/123456789/2193/1/25386.pdf

Shah, S.W. A. (2007) North-West Frontier Province: History and politics. National Institute of Historical and Cultural Research, Centre of Excellence, Quaid-i-Azam University, Islamabad.

http://nihcr.edu.pk/Downloads/PDF\%20Books/NWFP\%20History\%20and\%20Politic s.pdf

Shaheen, I., \& Khan, M. A. (2020). An Appreciation of Sir Alexander Cunningham's Explorations at Taxila in the Light of His Methodological Framework. FWU Journal of Social Sciences, 14(4), 140-148. http://121.52.146.40/fwujournal/index.php/ojss/article/view/135

Singh, U. (2004). The discovery of ancient India: Early archaeologists and the beginnings of archaeology. Permanent Black.

Trigger, B. G. (1989). A history of archaeological thought (2 ${ }^{\text {nd }}$ Ed.). Cambridge University. 


\section{Notes:}

${ }^{1}$ This paper is based on a part of the author's PhD dissertation (Shaheen 2016).

${ }^{2}$ About the importance of travelers' accounts, a writer says: 'To sum up, Travellers' accounts have indeed, inspired much later archaeological work and have been a valuable source of information much acknowledged and used in later traditions. Their vivid descriptions of what they saw and heard treat time as a united entity whether combining natural landscape and ancient monuments in their existing settings or mixing stories from mythology and contemporary everyday life. The significance of their accounts is even greater than those of concurrent historians because they are personal documents expressing thoughts and feelings quite freely; in this way they serve as brilliant and vibrant primary sources for the present historian and archaeologist. On the other hand, it has been noted that Travellers often viewed the landscape 'through the filter of their own experiences' (Bennet et al., 2000, p. 344) and therefore, their accounts should not be treated as objective beyond doubt images of a specific area/time, but they should be studied in relation to other documentary, but also archaeological evidence' (Gkiasta, 2008, p. 14).

${ }^{3}$ Cunningham followed the following order in his exploration and visited 32 different areas in the then Punjab (of which Peshawar valley made part at that time). It was in 1901 that the Trans-Indus areas such Peshawar valley and other neighbouring districts and Abbotabad and Mansehra were joined to constitute a new province named as North-West Frontier Province (recently re-named as Khyber-Pakhtunkhwa) (see for formation of North-West Frontier Province, Shah 2007). Areas surveyed by Cunningham (8171: 86): Peshawar, Charsadda, Palodheri, Hund, Lahore (Swabi), Aornos, Taxila, Hasan Abdal, Baoti-pind, Balar, Badalpur (Badarpur of Cunningham), Jaoli, Tarnawa, Kurmal (including the famous site of Kalawan), Rawalpindi, Manikyala, Sakrabasti, Dilawar, Mong, Katas, Sangala-wala-tiba or Sangala, Asarur, Ran-si, Amba-kapi, Sarhind, Thanesur, Amin, Pehoa, Sugh, Ilaridwar, Moradhwaj, Chaturbhuj.

${ }^{4}$ For a broader discussion about locating indigenous viewpoint in the development of orientalism in Indian case, see Oberoi (n.d.); cf. Singh 2004.

${ }^{5}$ A similar thought appears somewhere else in Cunningham. He opines: 'There is, however, one trait of the customs of the people of Taxila, recorded by Q. Curtius, which is so peculiar that, when we find it afterwards mentioned not only by Philostratus but by the Chinese Fa-Hian [Faxian] in A.D. 400, we can scarcely come to any other conclusion than that the people of Taxila were of the same race at these two distant periods. Cutius relates that Taxiles entertained Alexander splendidly for "three days." According to Philostratus, the King of Taxila was addressed by Appollonious in these words: "I have been now three days your guest and, on the morrow, I mean to take my departure in compliance with your law." The statement of the pilgrim refers to the neighbouring district of Udyâya, and not to Taxila itself, but the two districts were only separated by the Indus and the people were most probably of the same race... The peculiar custom of the country is thus described by Fa-Hian [Faxian]: "If any foreign ecclesiastic arrives, they are all ready to entertain him for 'three days;' after which they bid him seek for himself another resting place." The continued observance of this peculiar custom would seem to show that the same people had occupied the country from the time of Alexander down to A.D. 400' (Cunningahm 1871: 6-7).

${ }^{6}$ A late colonial work refers to the conservation programme and lauds the achievements in this regard. 'If in any respect Indian archaeology is ahead of other oriental countries, it is in the organization for the preservation of its monuments. This position is due to the early recognition of the necessity of a campaign against the destructive forces of nature. During the early days of the Survey under General Sir Alexander Cunningham, the function of preservation was left entirely to the Local Governments. Thanks to the comprehensive scheme launched by the late Lord Curzon the main lines of approach to the great problem of the conservation of all the national monuments of India were laid once for all in the beginning of the twentieth century... In India the suspension of preservation work for even a short period would seriously damage the monuments, and the gardens around the principal buildings would speedily become a mass of jungle' (Dikshit 1939a, p. 34). Dikshit identifies a number of degeneration agent such as natural and human and elaborates upon conservation activities in the face of such threats (Dikshit 1939a, p. 34). 